\title{
Size and value effects in Suriname
}

\author{
Denice Bodeutsch \\ Anton de Kom University of Suriname \\ Philip Hans Franses \\ Erasmus School of Economics
}

Econometric Institute Report 2013-31

\begin{abstract}
This paper studies the link between stock returns and size and book-to-market equity effects for 10 companies listed at the Suriname Stock Exchange. We analyze the cross-sectional variation in average returns and we find that there is apparently no size effect, but there is a value effect. The findings are broadly in line with those for other emerging markets documented in the literature.
\end{abstract}

This version: November 212013

Key words: Stock returns; Emerging market; Market capitalization; Book-to-market equity effects; Fama-French regression

JEL Code: G15 


\section{Introduction}

Emerging markets have grown rapidly and have received much attention in the past years. According to Barry et al. (1998) and Fama and French (1998), these markets are generally related to high returns and high volatility. Hence, there is a growing interest for factors determining stock returns on emerging markets.

Prior studies concerning the determinants of stock returns in developed markets (largely limited to the US) have produced results in which a number of firm-specific factors contribute in explaining the cross-section of average returns. Banz (1981) presents in perhaps the first relevant empirical paper evidence on the relation between (firm size) and US stock returns. Stattman (1980) and Chan et al. (1991) find a positive relation between the book-to-market equity ratio of a company and the average returns on US and Japanese stocks. Fama and French (1992) provide evidence that a combination of size (ME) and book-to-market equity (BE/ME) is better able to capture the cross section of stock returns than the market betas alone. In addition, Basu (1983) finds a positive relation between earnings-to-price ratio $(\mathrm{E} / \mathrm{P})$ and the average returns on US stocks. These studies indicate that the average returns of small stocks are higher than those of large stocks (known as the size effect), and that stocks with high BE/ME and E/P ratios have on average higher returns than stocks with low ratios. This is called the value effect.

For emerging markets, a number of empirical studies have also demonstrated that size and value factors play a significant role in explaining the performance of stock returns; see for example Fama and French (1998), Claessens et al. (1998) and Barry et al. (2002).

In this paper we investigate whether size and value effects play a major role in explaining the behavior of stock returns, where we focus on the Suriname Stock Exchange (SSE), a stock exchange that has never been analyzed as such. The SSE is a young and growing market in the Caribbean area, where Suriname is located north of Brazil and is bordered by Guyana and French Guyana to the west and east, respectively. The SSE represents an underdeveloped market as compared to developed markets and various other emerging markets, due to a relatively limited trading and a small number of listed companies. The market is also quite illiquid. For more details, see Bodeutsch and Franses (2012).

Our study builds on the research of Fama and French (1992) where we investigate the relation between stock returns and size (ME), book-to-market equity ratio (BE/ME), and 
earnings-to-price ratio (E/P). We extend the empirical evidence on emerging markets to Suriname by using data of 10 of the listed companies (for which we could collect the data) of the SSE for the period 2003 to and including 2012. These accounting variables, that is, market value of equity, book-to-market equity and earnings-price ratios, seem able to capture the crosssectional variation in average returns even though they have some peculiar properties (as we will discuss in the data analysis section). The results are broadly in line with those for other emerging markets documented in the literature. As a courtesy to the reader we present the data in the appendix, as these data have never been compiled and published before.

The outline of our paper is as follows. In Section 2, we discuss some elements of the relevant literature on size and value effects of a number of developed and emerging stock markets. In Section 3, we describe the data collection and in Section 4 we turn to the data analysis. We conclude with a discussion and the main implications from our study.

\section{Relevant literature}

The seminal study by Fama and French (1992) presents evidence that the factors size (market capitalization, $\mathrm{ME})$ and book-to-market equity ratio $(\mathrm{BE} / \mathrm{ME})$ have explanatory value for the cross-section of returns on US stocks. These factors are capable of explaining variation in returns beyond market risk. They examined the combined role of market beta $(\beta), \mathrm{ME}, \mathrm{E} / \mathrm{P}$, leverage and $\mathrm{BE} / \mathrm{ME}$ in the cross-section of average returns of US stocks for the period 1963 to and including 1990. The results indicate a negative relation between ME and average stock returns. With

regard to $\mathrm{BE} / \mathrm{ME}, \mathrm{E} / \mathrm{P}$ and the average returns there is a positive relation, implying that high $\mathrm{BE} / \mathrm{ME}$ and high $\mathrm{E} / \mathrm{P}$ stocks have higher average returns than stocks that are low on $\mathrm{BE} / \mathrm{ME}$ and E/P.

Fama and French (1998) extend this type of research to other developed countries with major markets and also to developing countries with emerging stock markets, where they address the sample-specific nature of their results. Interestingly, the negative relationship between size and stock returns is also found in emerging markets, that is, stocks of small firms have higher average returns than stocks of large firms. Furthermore, the authors document international evidence which captures the value premium in stock returns generated by $\mathrm{BE} / \mathrm{ME}, \mathrm{E} / \mathrm{P}, \mathrm{C} / \mathrm{P}$ and 
Div/P (the ratio of dividends over price). Fama and French (1998) report that the value premium is a compensation for risk associated with relative distress. Hence, firms with high $\mathrm{BE} / \mathrm{ME}, \mathrm{E} / \mathrm{P}$, $\mathrm{C} / \mathrm{P}$ and Div/P, which are also known as value firms (firms in distress and poor earnings), have high average returns. At the same time, firms with low BE/ME, E/P, C/P and Div/P, which are labeled as growth firms (firms with high earnings), have lower average returns.

Claessens et al. (1998) study the relationship between stock market returns and size and value effects using cross-sectional stock returns from 19 emerging markets for the period 19861993. Some of the results presented in this study are in contrast with the results documented for developed markets. Remarkably, in 11 of the 19 studied markets it is found that size is positively related to stock returns, meaning that stocks of larger firms create higher returns. They also documented evidence of $\mathrm{BE} / \mathrm{ME}$ effects, but the direction is also often opposite to the results of Fama and French (1998). With regard to E/P, for 6 of the markets it has a positive effect on stock returns, and this is on par with the results of Fama and French (1992), while for the remaining 13 markets no significant relation is found between $\mathrm{E} / \mathrm{P}$ and stock returns.

Barry et al. (2002) indicate in their research that the legitimacy of size and value effects based on BE/ME has been disputed by a number of authors. Some of the discussions are whether such effects hold generally or whether they are specific for the chosen sample or due to the different methodologies employed. Hence, these authors examine the robustness of the size and value effects using a sequence of different methodologies. This results in new evidence on the size and BE/ME effects in 35 emerging markets for the period 1985-2000. Their evidence strongly supports the presence of a book-to-market effect of the same kind as in other markets, but the evidence is considerably weaker for the size effect.

Recently, Borys and Zemčik (2011) focus on the occurrence of size and value effects on emerging stock markets in the Visegrad countries. Following Barry et al. (2002), they also raise some issues to define the behavior of stock market returns. The issues stated are whether the size and value effects are an international development and not confined to the US and whether the relationship between stock returns and size and value factors have a global or country-specific character. Their results indicate that size and book-to-market equity do have an effect on stock returns, albeit that the effects are smaller than those obtained in Fama and French (1998). 


\section{Data collection}

Our study uses data from 10 of the listed companies of the Suriname Stock Exchange (SSE) from 2003-2012, and these are the 10 for which we could collect data. For 2 other companies there were too many missing data. Whereas financial data of emerging stock markets is widely available, data on the SSE is not easily accessible. It took us half a year to collect the data, which was mainly due to the fact that we had to personally collect the annual reports which are not always publicly available. The returns data are derived from the half-monthly reports of the SSE which are the result of a manual trading system; see Bodeutsch and Franses (2012). The data to construct the firm-specific factors are derived from the companies' annual reports. Due to the public unavailability, the annual reports (2003-2011) were collected in various different ways. We contacted the listed companies, we consulted the companies' websites (if available) and we collected data straight from the SSE. Also, it turned out possible to obtain certain annual reports from the Chamber of Commerce and Industry of Suriname.

We use market capitalizations to create the size factor. Size (ME) is calculated by the number of shares outstanding multiplied by a stock's closing price. The firm-specific factors that we analyze to examine the value effect are the book-to-market equity ratio and the earnings-toprice ratio (the inverse of price-to-earnings ratio). Book-to-market equity (BE/ME) is the ratio of the book value of common equity to its market value and earnings-to-price $(\mathrm{E} / \mathrm{P})$ is the ratio of earnings per share to a stock's closing price.

In the Figures 1 to 4 we provide an overview of the development of the stock prices, market value, book value and earnings per share of the 10 companies listed on the SSE for the period 2003 to 2012. As a courtesy to the reader, we provide the data we collected in the Data Appendix. An NA marks a missing value.

\section{Data analysis}

We have annual data on 10 stocks for the end period 2003 to and including 2012. For each year $T$, we run the familiar regression 


$$
\log P_{i, T}-\log P_{i, T-1}=\alpha_{T}+\beta_{1, T} \log M E_{i, T-1}+\beta_{2, T} \log \frac{B E_{i, T-1}}{M E_{i, T-1}}+\beta_{3, T} \log E P S_{i, T-1}+\varepsilon_{i, T}
$$

where $\log$ denotes the natural logarithm and where $i=1,2, . ., 10$, and $P$ is the stock price, $M E$ is market value (size), BE is book value and EPS is earnings per share. We have no data on dividend payments, so this variable is not included.

We have collected data for 10 listed firms for the years 2003 to and including 2012. Due to the time lag, we lose 2003 as it is the first T-1 observation. For the years 2003-2004 there are some missing data for the Surinamese Brewery and for CIC, and for the years 2003-2005 data are missing for Elgawa; see the Data Appendix. In Table 1 we will each time present the actual sample size used.

Based on Fama and French (1992) we would expect $\beta_{1}$ in (1) to be negative, $\beta_{2}$ to be positive and $\beta_{3}$ to be positive too. Table 1 presents the Ordinary Least Squares (OLS) based estimation results for each of the years 2012 to 2004 . We see diversity of parameter estimates, where sometimes estimates are positive, sometimes negative, and in many cases insignificant. However, when we consider all equations as being part of a larger system, as in Table 2, we observe that the estimate of $\beta_{2}$ has the expected sign, is significant, and has a value which is quite close to the value in Table III of Fama and French (1992).

\section{Conclusion}

This paper has considered the 10 foremost important companies in Suriname, their stock market performance and the link between that performance and fundamentals. Using the approach of Fama and French (1992), we have found that there is apparently no size effect, but there is a value effect. Book-to-market equity (BE/ME), which is the ratio of the book value of common equity to its market value has the expected positive effect on stock returns. This ratio acts as a measure for past performance. Companies with a high $\mathrm{BE} / \mathrm{ME}$ ratio (known as value firms) are related to poor performance in the past (low stock prices, poor earnings, and distress). So, also in Suriname, value firms have high stock returns which can be seen as an important factor for the 
Surinamese market and ultimately the investor. We could not find any significant size effects in Suriname, but this may also be due to the small sample. Anyway, the sign of the size effects is different than usually encountered (as it is positive), and this corroborates well with the findings in related studies on emerging markets.

The implications of our study are the following. Up till now, the Suriname Stock Exchange has not been fully considered as a source of capital. However, Suriname can benefit from the evidence of our study for the following reasons. Fama and French (1992) and others report that size and book-to-market equity are considered as variables which can provide information from stock prices about risk and expected returns. Value and growth are two fundamentals for stock selection and these reported variables can thus be useful. Value firms are perceived as underpriced firms (cheap stocks) and not appreciated by the market. If the Surinamese market realizes that the prospects of value firms are not as weak as proposed by the developments in the recent past, the stock price will increase and this in turn could result in investors gaining an interest in those firms. Value investors have been rewarded with a large risk premium.

In addition, value firms not listed on the SSE, seeking capital to finance their growth, can be motivated to be listed on the SSE. According to the indicators size (measured by the number of companies listed and the MCAP/GDP ratio) and liquidity (measured by turnover/GDP and turnover ratio), the SSE has not grown remarkably in the past years (see Bodeutsch and Franses, 2012). As a result, these firms can ensure that the number of firms listed on the SSE increases. However, in order to stimulate the development of the SSE which can propel economic growth, the Surinamese government should facilitate better stock market performance through for example improved disclosure requirements and settlement procedures. 


\section{Data Appendix}

\section{Stock prices}

$\begin{array}{rrrrrrrrrrr} & 2003 & 2004 & 2005 & 2006 & 2007 & 2008 & 2009 & 2010 & 2011 & 2012 \\ & & & & & & & & & & \\ \text { Varossieau } & 6.75 & 8 & 9 & 9 & 16 & 16.6 & 16.6 & 16.85 & 22 & 27.5 \\ \text { Self Reliance } & 1.82 & 9.2 & 9.3 & 8.6 & 8.6 & 9.1 & 9.5 & 11 & 11 & 18 \\ \text { VSH Foods } & 3.7 & 4.95 & 5.2 & 5.2 & 5.2 & 5.45 & 5.6 & 5.6 & 5.6 & 6.1 \\ \text { Brewery } & 28.82 & 35 & 51 & 73 & 98 & 125 & 225 & 290 & 395 & 735 \\ \text { CIC } & 2.25 & 3.25 & 6.1 & 6.8 & 6.8 & 8 & 8 & 8 & 8.25 & 9 \\ \text { DSB } & 5 & 7.3 & 7.68 & 9 & 47.25 & 20 & 25.5 & 40 & 71 & 96.75 \\ \text { Elgawa } & 1.2 & 1.2 & 1.6 & 1.8 & 6 & 8 & 8 & 60 & 60 & 150 \\ \text { Assuria } & 4.7 & 5.5 & 2.5 & 11.6 & 15.5 & 19.05 & 22.25 & 30 & 46 & 78 \\ \text { Hakrinbank } & 79.2 & 106 & 124 & 136 & 150 & 174 & 190 & 205 & 225 & 295 \\ \text { Torarica } & 19 & 24.5 & 27.5 & 36.6 & 39.22 & 42 & 57 & 58 & 65.3 & 70\end{array}$

\section{Market value}

$\begin{array}{lrrrrrrrr}2003 & 2004 & 2005 & 2006 & 2007 & 2008 & 2009 & 2010 & 2011 \\ 2341642 & 2775280 & 3122190 & 3122190 & 10830528 & 11236672 & 11236672 & 11405899 & 14891976 \\ 2373309 & 11996947 & 16746510 & 15487662 & 15487662 & 16388108 & 17108464 & 19809801 & 19809801 \\ 4823690 & 6453315 & 6779240 & 6779240 & 6779240 & 7105165 & 7300720 & 7306320 & 7306320 \\ \text { NA } & \text { NA } & 4837860 & 6924780 & 9296280 & 11857500 & 21343500 & 27509400 & 37469700 \\ \text { NA } & \text { NA } & 30512420 & 34014960 & 34014960 & 40017600 & 40017600 & 40017600 & 41268150 \\ 43600000 & 63656000 & 66969600 & 78480000 & 411547500 & 174200000 & 222105000 & 348400000 & 618410000 \\ \text { NA } & \text { NA } & \text { NA } & 862380 & 2874600 & 3832800 & 3832800 & 5585634 & 5584800 \\ 25304635 & 88835450 & 161518750 & 74957228 & 101410765 & 124843641 & 145820069 & 196611330 & 301474754 \\ 36883123 & 49363776 & 57746304 & 63334656 & 69854400 & 81031104 & 88482240 & 95467680 & 104781600 \\ 18430000 & 24354715 & 27336925 & 48510372 & 51982972 & 55667640 & 75548940 & 76874360 & 86549926\end{array}$

Note: the rows associate with the same companies as in the table for Stock Prices. 


\section{Book value}

$\begin{array}{rrrrrrrrr}2003 & 2004 & 2005 & 2006 & 2007 & 2008 & 2009 & 2010 & 2011 \\ & & & & & & & & \\ 3084924 & 3630388 & 4250824 & 5729473 & 6121734 & 6586155 & 12032489 & 14344903 & 13174685 \\ 10130094 & 11805245 & 22698604 & 20165479 & 23521840 & 26737283 & 31145748 & 39065202 & 53495906 \\ 6841781 & 7020062 & 7171736 & 5798243 & 6004422 & 6191081 & 7117852 & 7758999 & 8307928 \\ \mathrm{NA} & \mathrm{NA} & 33567203 & 36408324 & 38455695 & 41704028 & 40431586 & 46816832 & 49223455 \\ \mathrm{NA} & \mathrm{NA} & 8939000 & 10126000 & 11048000 & 12093000 & 20304000 & 21375000 & 20650017 \\ 26776000 & 48560000 & 59947000 & 73300000 & 94335000 & 111015000 & 125395000 & 150111000 & 180148000 \\ \mathrm{NA} & \mathrm{NA} & \mathrm{NA} & 7887000 & 9256000 & 9691000 & 10449000 & 12669000 & \text { NA } \\ 34645000 & 58040000 & 69197425 & 89135891 & 106817961 & 120566494 & 137376595 & 160826106 & 202951935 \\ 11971828 & 15543068 & 21230689 & 33237684 & 43305390 & 54471081 & 75371359 & 88325937 & 109275975 \\ 26706000 & 28267000 & 35189978 & 47135227 & 50141539 & 53767118 & 56271051 & 58231951 & 60765027\end{array}$

Note: the rows associate with the same companies as in the table for Stock Prices.

\section{Earnings per share}

$\begin{array}{rrrrrrrrr}2003 & 2004 & 2005 & 2006 & 2007 & 2008 & 2009 & 2010 & 2011 \\ & & & & & & & & \\ 1.06 & 2.37 & 2.59 & 4.23 & 2.99 & 3.29 & 4.26 & 6.14 & 0.99 \\ 3.32 & 1.54 & 1.97 & 1.93 & 1.34 & 2.02 & 2.69 & 5.11 & 7.55 \\ 0.26 & 0.29 & 0.24 & 0.24 & 0.3 & 0.28 & 1.19 & 0.81 & 0.73 \\ 42.97 & 55.92 & 77.91 & 118.83 & 138.79 & 186.94 & 197.59 & 274.25 & 327.09 \\ \mathrm{NA} & \mathrm{NA} & 0.31 & 0.35 & 0.39 & 0.23 & 1.18 & 0.37 & 0.06 \\ 0.31 & 0.45 & 1.65 & 1.88 & 10.3 & 2.61 & 2.4 & 3.15 & 4.10 \\ \mathrm{NA} & \mathrm{NA} & \mathrm{NA} & 2.48 & 3.54 & 1.66 & 2.08 & 25.26 & \mathrm{NA} \\ 0.22 & 1.12 & 0.47 & 1.86 & 1.91 & 1.63 & 2.41 & 2.89 & 3.79 \\ 7.87 & 11.79 & 18.2 & 27.41 & 32.84 & 36.15 & 39.06 & 42.74 & 53.80 \\ 1.48 & 1.84 & 2.54 & 2.01 & 3.14 & 3.52 & 2.41 & 1.56 & 1.24\end{array}$

Note: the rows associate with the same companies as in the table for Stock Prices. 
Table 1: estimation results (White-corrected) standard errors in parentheses for each of the years 2003 to 2012.

$\begin{array}{llllll}\alpha & \beta_{1} & \beta_{2} & \beta_{3} & \mathrm{R}^{2}\end{array}$

Year

2012

$-1.034 \quad 0.074$

0.175

0.036

0.639

(1.179)

$(0.069)$

$(0.168)$

(0.032)

2011

$-1.226$

0.077

$-0.102$

0.037

0.544

(0.075)

(0.233)

(0.044)

2010

$$
-1.533
$$

0.118

1.029

$-0.154$

0.492

(2.502)

(0.151)

(0.651)

(0.113)

2009

$$
-0.921
$$

0.060

0.121

(0.088)

0.042

0.632

(0.457)

(0.027)

(0.038)

2008

$$
1.101
$$

$-0.059$

0.188

$-0.035$

0.524

(1.358)

(0.082)

(0.154)

(0.059)

2007

$-2.696$

0.185

(3.960)

(0.248)

0.531

(0.334)

$-0.105$

0.286

2006

$-5.361$

0.338

0.297

(0.120)

(sample is 9)

(3.761)

(0.233)

0.224 )

$-0.066$

0.445

2005

$$
2.767
$$

$-0.169$

$-0.152$

(0.074)

(sample is 7)

(3.081)

(0.194)

(0.423)

0.039

0.312

2004

$$
-1.070
$$

0.089

(3.183)

(0.199)

0.560

$(0.339)$

(0.120)

0.197

0.662

(sample is 7)

(3.183) 
Table 2: estimation results (White-corrected) standard errors in parentheses for two systems of equations (in boldface and italics are the $5 \%$ significant parameter estimates)

$\begin{array}{llll}\alpha & \beta_{1} & \beta_{2}\end{array}$

$\begin{array}{lllll}\text { System 1 } & & \begin{array}{l}0.063 \\ (0.049)\end{array} & \begin{array}{l}\mathbf{0 . 2 6 2} \\ (0.094)\end{array} & \begin{array}{l}-0.016 \\ (0.029)\end{array} \\ \text { System 2 } & & & & \\ & -0.897 & 0.068 & \mathbf{0 . 2 9 8} & -0.025 \\ & (0.792) & (0.047) & (0.094) & (0.028)\end{array}$

Note to the table: Systems 1 and 2 assume that the parameters in (1) are equal across equations. System 1 sets the intercept term equal to 0, while System 2 allows it to be equal across equations. 


\section{Figures}

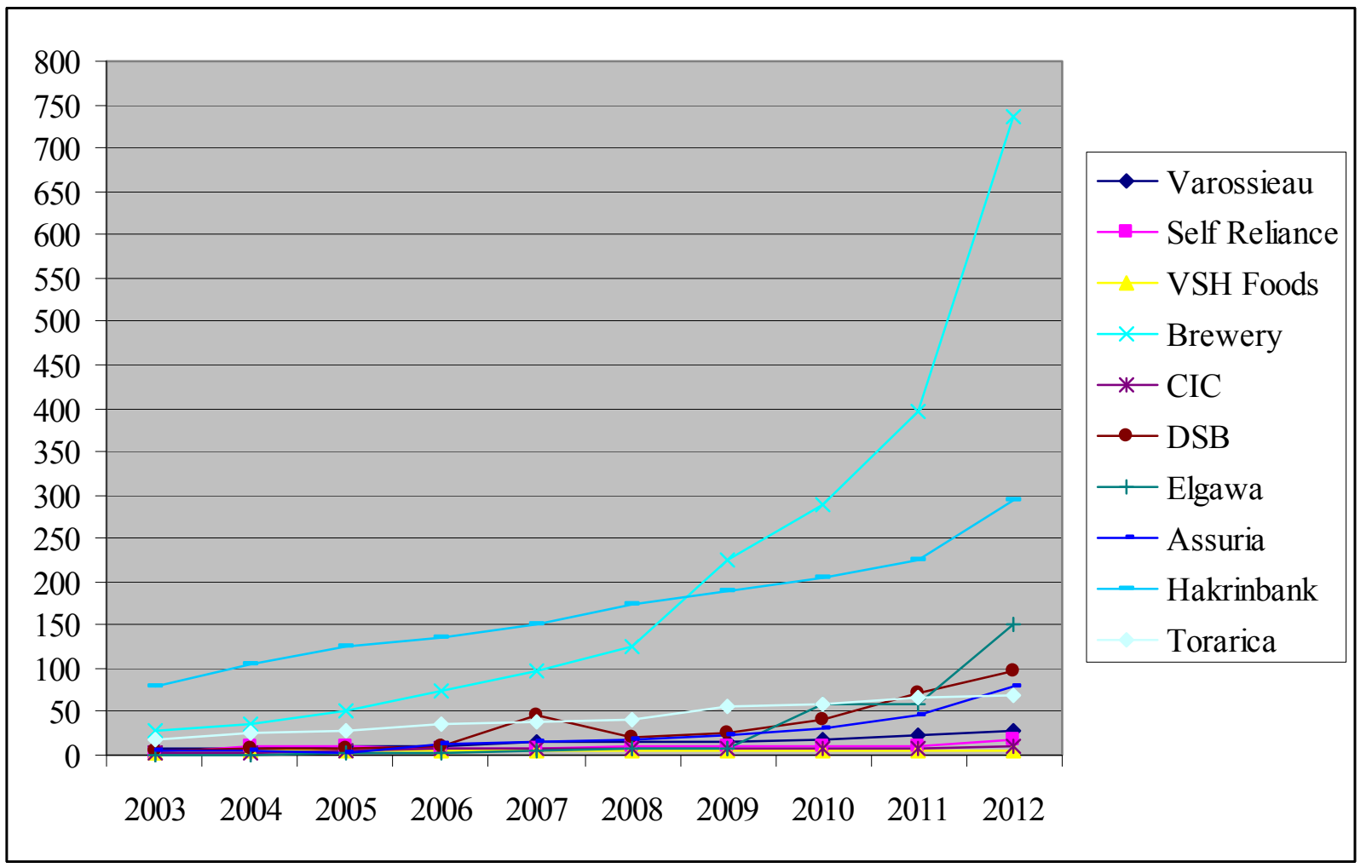

Figure 1: Closing stock prices of the 10 companies listed on the SSE in local currency (SRD) for the end period 2003-2012. Source: Half monthly reports SSE 


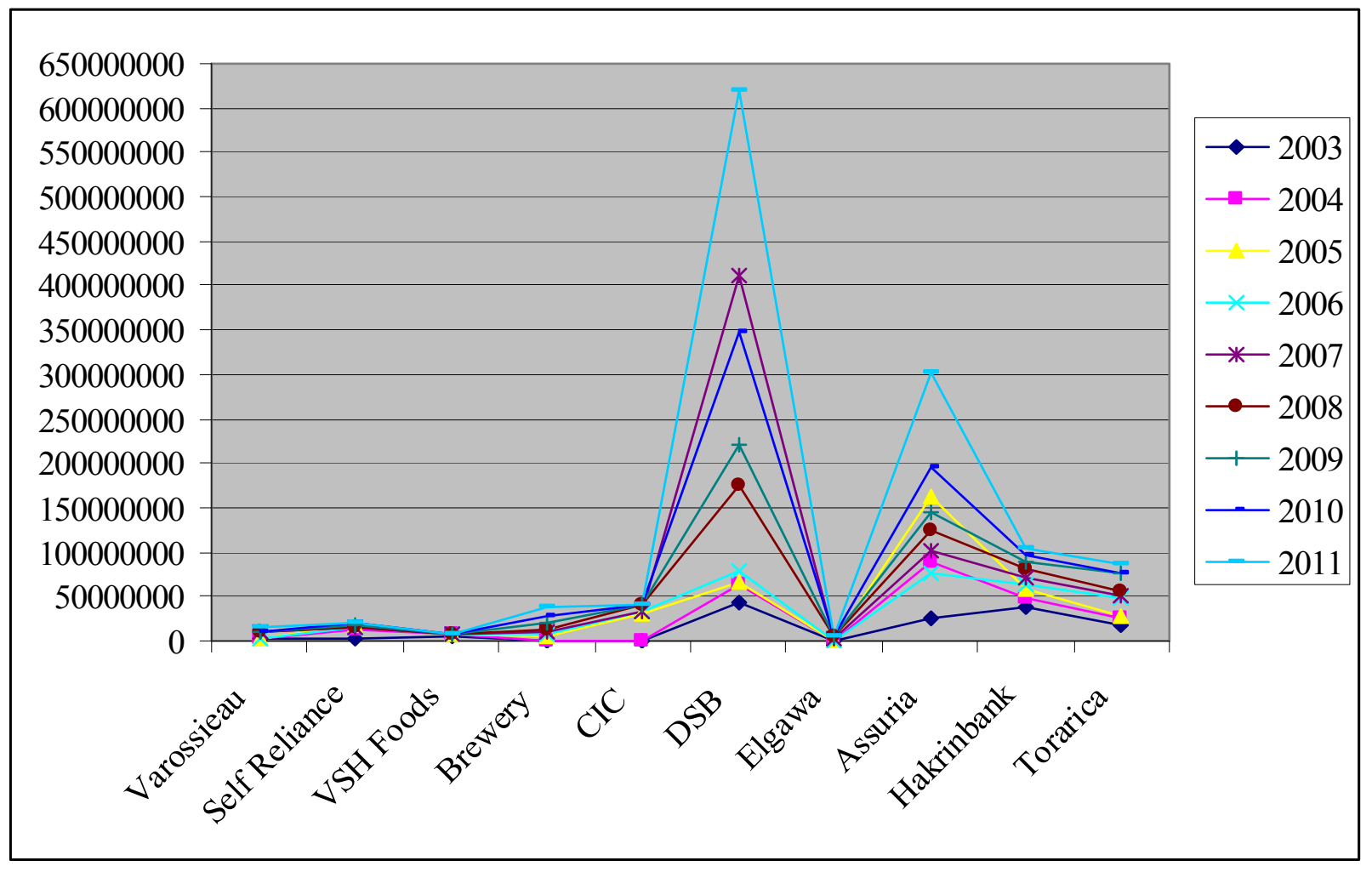

Figure 2: Market value of the common stocks of the 10 companies listed on the SSE in local currency (SRD) for the end period 2003-2011. 


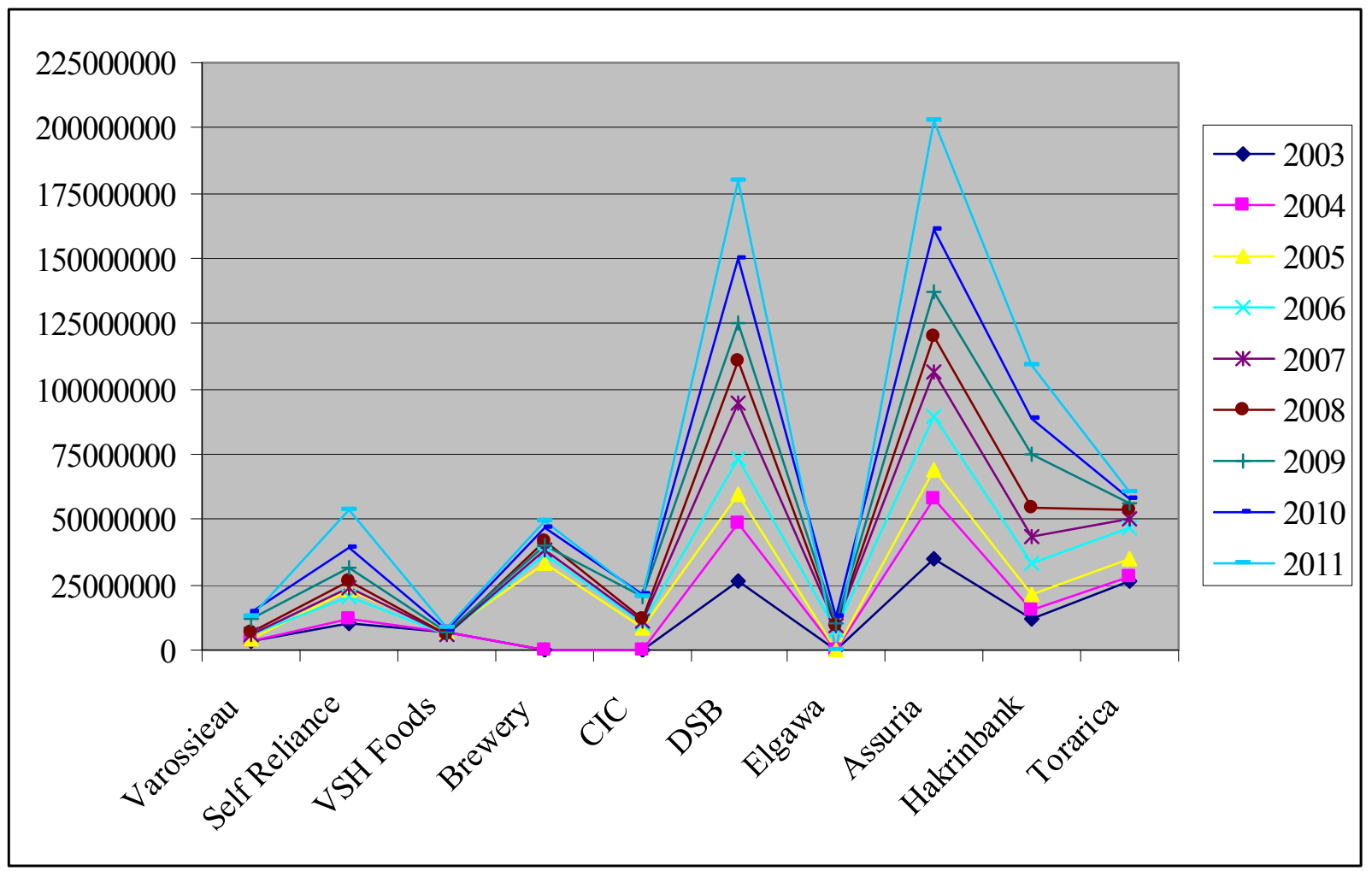

Figure 3: Book value of the 10 companies listed on the SSE in local currency (SRD) for the end period 2003-2011. 


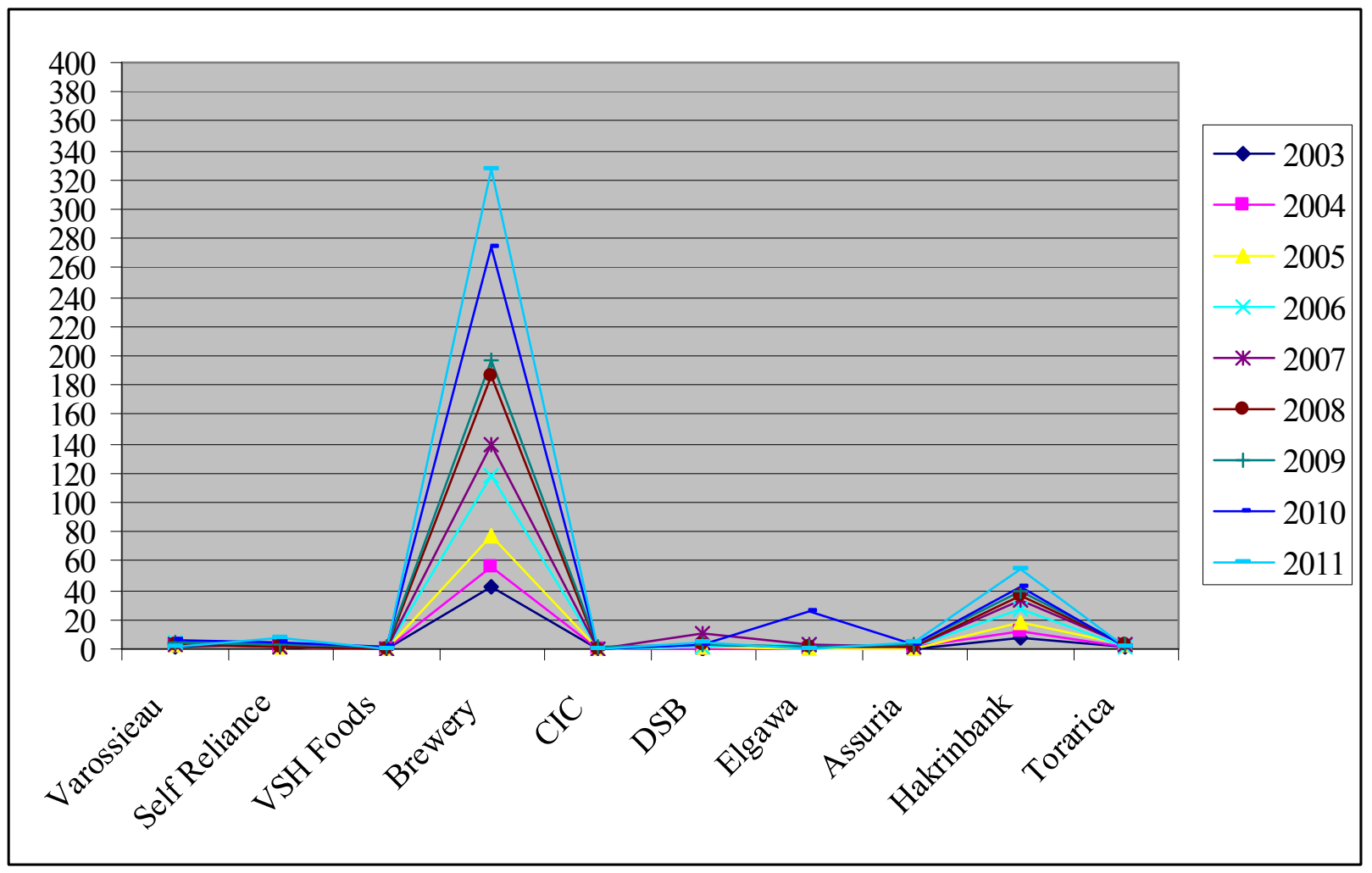

Figure 4: Earnings per share in local currency (SRD) for the 10 companies listed on the SSE for the end period 2003-2011. 


\section{References}

Banz, Rolf W. (1980), The relationship between return and market value of common stocks, Journal of Financial Economics, 9 (1981), 3-18.

Barry, Christopher B., John W. Peavy III and Mauricio Rodriquez (1998), Performance characteristics of emerging capital markets, Financial Analysts Journal, 54 (1), 72-80.

Barry, Christopher B., Elizabeth Goldreyer, Larry J. Lockwood and Mauricio Rodriguez (2002), Robustness of size and value effects in emerging equity markets, 1985-2000, Emerging Markets Review, 3, 1-30.

Basu, Sanjoy (1983), The relationship between earnings yield, market value, and return for NSYE common stocks: Further evidence, Journal of Financial Economics 12, 129-156.

Bodeutsch, Denice and Philip Hans Franses (2012), The stock exchange of Suriname: Returns, volatility, correlations and efficiency, Econometric Institute Report 2012-017, Erasmus School of Economics.

Borys, Magdalena M. and Petr Zemcik (2011), Size and value effects in the Visegrad countries, Emerging Markets Finance and Trade, 47 (3), 50-68.

Claessens, Stijn, Susmita Dasgupta and Jack Glen (1998), The cross-section of stock returns: Evidence from emerging markets, Emerging Markets Quarterly 2, 4-13.

Chan, Louis, K.C., Yasushi Hamao and Josef Lakonishok (1991), Fundamentals and stock returns in Japan, Journal of Finance, 46 (5), 1739-1764.

Fama, Eugene F. and Kenneth R. French (1992), The cross-section of expected stock returns, Journal of Finance, 47, 427-465. 
Fama, Eugene F. and Kenneth R. French (1998), Value versus growth: The international evidence, Journal of Finance, 53, 1975-1999.

Stattman, Dennis (1980), Book values and stock returns, The Chicago MBA: A Journal of Selected Papers 4, 25-45. 